Egyptian J. of Nutrition Vol. XXXIV No. 3 (2019)

\title{
Effect of irradiated almond and hazelnut enriched- diet on biochemical aspects in rats
}

\author{
Ayat L. K. Soude ${ }^{1}$, Hania F. G. El-Neily ${ }^{1}$ \\ And Ashraf A. Abd El-Megeid²
}

1- Food irradiation Department, Industrial Irradiation Division, National center for radiation Research and Technology, Cairo, Egypt.

2- Nutrition and Food Science Department, Faculty of Home Economics, Helwan University, Cairo, Egypt.

\section{Abstract}

The present study aims to evaluate effect of irradiationatdoses $6 \mathrm{kGy}$ and $10 \mathrm{kGy}$ on chemical and biochemical parameters of nuts including almond (Prunusamygdalus)andhazelnut (Corylusavellana). 70 albinoratsused in this study, the rats divided into 7 groups as following: Group (1): fed on basal diet, as a control group. Group (2): fed on basal diet containing un-irradiated almond. Groups (3 and 4): fed on diets containing the irradiated almond on 6 and 10kGy, respectively. Group (5): fed on basal diet containing unirradiated hazelnut. Groups (6 and 7): fed on diets containing the irradiated hazelnut on 6 and $10 \mathrm{kGy}$, respectively for 8 weeks. The statistical analysis of irradiated almond and hazelnutat dose 6 and 10 kGy at zero time and storage for 6 months on its approximate analysis showed no significant difference in protein, moisture, ash and lipid. The biochemical performance showed non-significant effect on organs weight, high density lipoprotein-cholesterol (HDL-c), low 


\section{Ayat L. K. Soude, Hania F. G. El-Neily \\ And Ashraf A. Abd El-Megeid}

density lipoprotein-cholesterol (LDL-c), blood hemoglobin, total cholesterol, triacylglycerol's, glucose, serum alanine amino transferase (ALT), serum aspertate amino transferase (AST), liver superoxide dismutase (SOD), liver glutathione peroxidase (GPX) and liver catalase in groups applied doses of non-irradiated or irradiated almond and hazelnut, when compared with control group which fed on basal diet, whileserum alanine amino transferase (ALT) which showed increased in untreated almond and decreased at untreated hazelnut and there were significant increase in antioxidant enzymes at all groups.

\section{Introduction}

Almond (PrunusamygdalusBatsch.) belongs to the family Rosaceae, which also includes apples, pears, peaches, and raspberries(Jahanban et al., 2010). Almonds (Prunusamigdalis) are a good dietary source of vitamin E, sterols, and flavonoids, each of which has been suggested to play a role in the promotion of health. In particular, increased consumption of flavonoids has been associated with an anti-obesity effect in women and reduced risk of stroke, cardiovascular disease, and some forms of cancer (Yochum et al., 1999).The composition of almond is $25.23 \%$ moisture, $5.00 \%$ ash; $32.73 \%$ lipid; $33.66 \%$ crude fibre; $3.11 \%$ crude protein and 25.47\% carbohydrate(Akpabio, 2012).

Omer et al., (2011)reported that,the amounts of oleic acid, linoleic acid, palmitic acid and stearic acid in Picantili, Ferraduel, were (57.46 to $68.65 \%, 11.77$ to $25.15 \%, 5.06$ to $7.26 \%$ and 1.26 to $2.41 \%$ ), respectively. Alisonand Oliver (2012)given their favorable fatty acid composition and high fiber content, the U.S. Food and Drug 


\section{Egyptian J. of Nutrition Vol. XXXIV No. 3 (2019)}

Administration (FDA) released a health claim recognizing that almonds can help maintain a healthy cholesterol level, particularly in patients with hypercholesterolemia. Nut consumption is not associated with a higher body math index (BMI) among free-living individuals. Almonds are low in available $\mathrm{CHO}$, have a healthy fatty acid profile, and are high in vegetable protein, fiber, and magnesium.

Almonds with skin, hull, and shell show a powerful capacity in collecting free radicals and this activity can be related to the presence of unsaturated fats, terpenoids, flavonoids, phenolic acids, and other beneficial compounds including fiber (Jahanban et al., 2010).Gamma irradiation could increase phenolic content in almond skin(Harrison and Were, 2007).

Hazelnuts (Corylusavellana) play a major role in human nutrition and health, because of their special composition of fat, protein, carbohydrate, vitamins, minerals and nutrients antioxidant (Alasalvar et al., 2009). Hazelnuts contain fat $60.8 \%$, protein $15.0 \%$ and fiber10.4\%(Salas-Salvadó., et al., 2006).On the other hand, (Alasalvar et al., 2006)reported that, hazelnut plays a major role in human nutrition and health because of its special composition of fat (around 60\%), most of which is highly rich in Monounsaturated Fatty Acids (MUFA) mainly oleic acid.

Hazelnut is a very rich source of energy providing approximately 6 to $6.5 \mathrm{kcals} / \mathrm{g}$ fresh seed. Fatty acids composition in Hazelnut play an important role in human health, in this respect (Connor, 2000, Aronson et al., 2001 and Iso et al ., 2002) reported that, the consumption of specific fatty acids such as omega- 3 fatty acids and oleic acid may provide health benefits. 


\section{Ayat L. K. Soude, Hania F. G. El-Neily \\ And Ashraf A. Abd El-Megeid}

Dietary compounds other than antioxidant vitamins may provide a critical role in protecting against Radical Oxygen Species ROS induced free radical injury. Phenolic compounds are found in virtually all plant foods and many phenols can act as powerful antioxidants that may reduce free radical damage. Individual phenolic compounds with known antioxidant activities have been identified in hazelnut including gallic acid, 4-OH benzoic acid, $p$-cou-maricsinaptic acid, and quercetin Hazelnut extracted with $80 \%$ Ethanol $\mathrm{OH}$ has also demonstrated antioxidant activities, hydrogen peroxide, superoxide, $\mathrm{DPPH}$, and $\beta$-carotene linoleate system. The hazelnut extract also inhibited human LDL oxidation and DNA scission. The oxygen radical absorbance capacity (ORAC) assay is a physiologically relevant antioxidant test because it measures the ability of an antioxidant system to inhibit the oxidative damage to susceptible molecules of peroxyl radicals Haiwen and John (2011) and Shahidi et al., (2007).

Food irradiation has been recognized and regulated as an effective food processing technology in many countries being able to destroy or reduce ubiquitous pests and pathogens that contaminate raw foods (Diehl, 1981).Radiation processing is well established as a physical, non-thermal method to preserve various food products that involves the exposure of food products (raw or processed) to ionizing or non-ionizing radiation (Antonio et al., 2012).Irradiation can also influence the levels of antioxidants/phytochemicals in plant products(Behgar et al., 2011).

Gamma radiation, more energetic than $\mathrm{X}$-rays, is used from sources of radioactive isotopes, cesium-137 or cobalt-60, and it is identified by the World Health Organization as a food preservation 
Egyptian J. of Nutrition Vol. XXXIV No. 3 (2019)

technique that improves food safety without altering the toxicological, biological or nutritional quality of the food (Farkas andMohácsiFarkas2011).Therefore, the present study was carried out to assess the effects of diet containing untreated and treated almond and hazelnut on healthy rats.

\section{Material and methods}

\section{Material:}

Almond (Prunusamigdalis), Hazelnut (Corylusavellana), sucrose, starch and corn oil were obtained from the local market, Cairo, Egypt.

Casein, all vitamins, minerals, cellulose, $\mathrm{L}$-Cystine and choline chloride were obtained from El-Gomhoriya company, Cairo, Egypt.

Kits: kits used to determine hemoglobin, glucose, AST, ALT, cholesterol, triglycerides; HDL-c andantioxidant enzymes including (malonaldehyed, GPX, Catalase and SOD) were obtained from Gama tread Company, Cairo, Egypt.

\section{Methods:}

\section{Y Irradiation treatment:}

Almond (Prunusamigdalis) and Hazelnut (Corylusavellana) were packed in polyethylene bags, and sealed by heat. Each bag contained about $200 \mathrm{~g}$. they were subjectedy Irradiation from $\mathrm{Co}^{60}$ at National Center for Radiation Research and Technology at Nasr City, Cairo Egypt. The facility used was Gamma Chamber 400 A, Co-60 facility of India. The doses applied were 6 and $10 \mathrm{kGy}$ delivered at dose rate of $1.606 \mathrm{kGy} / \mathrm{h}$ as calibrated using small pieces of radiochromic film (Maclaughlin et al., 1985)at the time of experimentation. The samples were stored at $5^{\circ} \mathrm{C}$ until used. 


\section{Ayat L. K. Soude, Hania F. G. El-Neily \\ And Ashraf A. Abd El-Megeid}

\section{Chemical composition of almond and hazelnut:}

Moisture content, crude fat, crude protein, ash content were determined according to the method described by the (A.O.A.C. 2003).The fatty acids compositionwere determinedasthe method described by (Hamilton and Hamilton, 1993).

\section{Diet preparation:}

The diets were prepared by using untreated and treated (almond and hazelnut) with irradiation. The diets were prepared according to (Reeves et al., 1993), the salt mixture was prepared according to (Hegested al., 1941) and the vitamin mixture was prepared according to (A.O.A.C. 2003).

\section{Experimental rats:}

Seventy male albino rats, Sprague-Dawley strain, with an initial weight of about $80 \pm 5 \mathrm{~g}$ were used in this study. They were obtained from animal house of National Center for Radiation Research and Technology, Atomic Energy Authority, Cairo, Egypt. The animals were housed individually in plastic cages with wire mesh bottoms at a room temperature of $22-25^{\circ} \mathrm{C}$ and $60 \pm 5 \%$ relative humidity, with a photoperiod of $12 \mathrm{~h}$ and water for eight week. Groups of ten rats were then assigned to receive one of seven experimental diets (i.e. control, untreated nuts and treated nuts with 6 and $10 \mathrm{kGy}$ irradiation) almond and hazelnut, alongside casein diet. All animals will be free access to feed and water on based diet for one week for adaptation. After this week, the rats divided into seven groups as the following: group 1 fed on basal diet as a control group, group 2, 3 and 4 were feed on untreated almond and treated almond with 6 and 10 kGy, respectively. Group 5, 6 and 7 were feed on untreated hazelnut and treated hazelnut with 6 and $10 \mathrm{kGy}$, respectively. 
Egyptian J. of Nutrition Vol. XXXIV No. 3 (2019)

During the experimental period (8 week), the diets consumed and body weights were recorded every week. At the end of the experiment period, the animals were fasted overnight, then the rats were anaesthetized and sacrificed, and blood samples were collected from the aorta. The blood samples were centrifuged and serum was separated to estimate some biochemical parameters, i.e. Serum cholesterol (Richmond, 1973), triglycerides (Stein, 1987),high density lipoprotein-cholesterol HDL-c (Firdewald et al., 1972), low and very low density lipoprotein-cholesterol LDL-C and VLDL-C (Firdewald et al, 1972), glucose(Young, 2001), aspartate amino transferase (AST) and alanine amino transferase (ALT) (Young, 1990). Hemoglobinwere estimated according to (Dacia, and Lewis. 1985).Liver and kidney were separated from each rat and weighted to calculate organs to body weight $\%$.

\section{Determination of antioxidant enzymes:}

Superoxide dismutases (SODs) are metabolioenzymes that catalyze the dismutation of the superoxide anion to molecular oxygen and hydrogen peroxide and thus forma crucial part of the cellular antioxidant defense mechanism (Nishikimiet al., 1972).

Cellular glutathione peroxidase (GPs) is a member of a family of GPx enzyme whose function is to detoxify peroxides in the cell. The GPx enzymes play a critical role in protecting the cell from free radical damage, particularly lipid peroxidation (Pagliaand Valentine1967).

Catalase is antioxidant enzyme that is present in the most aerobic cells. Its serves as one of the body's defense systems against $\mathrm{H}_{2} \mathrm{O}_{2}$ a strong oxidant that can cause intracellular damage(Aebi, 1984). 


\section{Ayat L. K. Soude, Hania F. G. El-Neily \\ And Ashraf A. Abd El-Megeid}

The data obtained was analyzed statistically for standard deviation and one way ANOVA test according to (Duncan, 1955).

\section{Result and discussion}

Effect of radiation processing with storage on chemical composition of nuts (Almond and Hazelnut).

The effect of radiation processing at ( 6 and $10 \mathrm{kGy}$ ) on the mean values of moisture, ash, crude protein, and crude fat of almond and hazelnut in zero time and after storage for 6 months presented in tables (1 and 2).

\section{1-1 Almond:}

The variation of moisture, ash, crude protein, and crude fat of almonds treated with irradiation at zero time and after storage for 6 months were studied, the results are presented in table (1).The mean values ofmoisture, protein, ash and crude fat in zero time does not change significantly in irradiated almonds at $6 \mathrm{kGy}$, except ash which showed significant decrease, ascompared to un-irradiated almonds (control). On the other hand, irradiated almonds with $10 \mathrm{kGy}$ caused significant decrease in moisture and ash, while the other nutrients showednon-significantchanges, as compared to un-irradiated almonds.

Results in this table indicated that, non-significant changed in moisture, crude protein, ash and crude fat in almonds treated with irradiation ( 6 and $10 \mathrm{kGy}$ ) after storage for 6 months, as compared to the control sample.Several authors agree with our previous mentioned results among them (Bhatti et al., 2013) reported that gamma irradiation exerted no considerable effect on the proximate 
Egyptian J. of Nutrition Vol. XXXIV No. 3 (2019)

almond seed composition. In addition to, Mahfouz, (2015)reported that the moisture, protein, lipid, and ash of almond nut were not substantially affected by gamma irradiation. Similar finding showed that gamma irradiation with doses up to $10 \mathrm{kGy}$ had no real effect on moisture, protein, lipid, fiber and ash of almond. During storage at room temperature, the total protein and total fat of almond nut also significantly $(p<0.05)$ increased in both irradiated and non-irradiated samples.(Bela et al., 2008 and Maityet al. 2009) reported that gamma irradiation could change the seed protein quantitatively, not the qualitatively.

\section{Hazelnut:}

The variation of moisture, ash, crude protein, and crude fat of hazelnut treated with irradiation at zero time and after storage for 6 months presented in tables (2).The data showed that there was a different in the mean values of moisture between the control sample and treated sample with (6 and $10 \mathrm{kGy}$ ). Total lipid also decreased significantlyin hazelnutwhich treated with irradiation at doses (6 and $10 \mathrm{kGy}$ ), as compared to un-treated sample.

At the storage (6 moths), the results in the same table indicated that, non-significant increase was observed in the moisture content of hazelnut which treated with irradiation at (6 kGy), while increased significantly with irradiation at (10 kGy), as compared to the control sample. This increase may be due to the humidity of atmosphere. Ash, protein and lipidcontent of hazelnut did not changed significantly with irradiation at (6 and $10 \mathrm{kGy}$ ) after storage period for 6 months, as compared to the control sample.

In this respect, (Saadetkoc and Ahmet2017)reported that, After irradiation, $0.5,1$ and $1.5 \mathrm{kGy}$ doses of gamma irradiation 


\section{Ayat L. K. Soude, Hania F. G. El-Neily \\ And Ashraf A. Abd El-Megeid}

significantly increased the total fat values $(p<0.05)$ and this value decreased during the storage. (Aycaet al., 2007)indicated that the low dose irradiation treatment slightly increased the total lipid content whereas it dramatically decreased for high dose treatment.

Fatty acids composition of un-treated and treated almond and hazelnut with two doses of irradiation at zero time and after storage for 6 months:

The fatty acids composition of two types of nuts sample exposed to different doses of irradiation are presented in table ( 3 and 4).

\section{Almond:}

The data in table (3) indicated that, at zero time the untreated almond (control) contains $7.42 \%$ saturated fatty acids (SFA) \{palmitic acid\} that was the major saturated fatty acid.

Treating almond sample with irradiation-increasedpalmitic acid by $2.4 \%$ and $28.0 \%$ at 6 and $10 \mathrm{kGy}$, respectively.Monounsaturated fatty acid (MUFA) \{Oliec acid\} of control sample was $73.74 \%$ that was the major (MUFA). After treated almonds with irradiation ( 6 and $10 \mathrm{kGy}$ ) oleic acid decreased by about (- $9.68 \%$ and $-2.7 \%)$, respectively.

Polyunsaturated fatty acids (PUFA) \{linoleic acid\} of raw sample was $18.8 \%$ that wasthe major (PUFA). The data indicated that the linoleic acid increased by $(+36.64)$ at $6 \mathrm{kGy}$ and decreased by $(-21.8 \%)$ at $10 \mathrm{kGy}$.

After storage almonds for 6 months, palmitic acid in almond which treated with 6 kGyincreased by about $13.6 \%$, oliec acid decreased by $10.49 \%$, and archidic was decreased by $27.1 \%$, while 


\section{Egyptian J. of Nutrition Vol. XXXIV No. 3 (2019)}

linoliec acid did not appeared. On the other hand,palmitic acid in irradiated almonds with $10 \mathrm{kGy}$ increased by $33.96 \%$, oliec acid decreased by $24.23 \%$, linoliec acid did not appeared and archidic increased by $34.45 \%$.

\section{Hazelnut:}

The data in table (4) indicated that, at zero time the raw hazelnut (control) contain $6.58 \%$ saturated fatty acids (SFA) \{palmitic acid\} that was the major saturated fatty acid. Treating hazelnut sample with irradiation decreasedpalmitic acid by $8.8 \%$ at $6 \mathrm{kGy}$ and increased by $6 \%$ at 10 kGy.Monounsaturated fatty acid (MUFA) (oliec acid) of control sample was $81.28 \%$ that was the major (MUFA). Oleic acid decreased by $(-8.5 \%)$ at $6 \mathrm{kGyand}$ by $(-2 \%)$ at 10 kGy.Polyunsaturated fatty acids (PUFA) \{linoleic acid\} of control sample was $8.19 \%$ that the major (PUFA). The data indicated that the linoleic acid change by $3.6 \%$ at $6 \mathrm{kGy}$ and by $5.6 \%$ at $10 \mathrm{kGy}$.

After storage for 6 months the fatty acid arachidic was appeared at 6 kGy (2.4\%). Palmitic acid increased by $72 \%$ at $6 \mathrm{kGy}$, Oliec acid decreased by $2.1 \%$ andlinoliec acid did not appeared, but at $10 \mathrm{kGy}$ (Palmiticacid decreased by $20.3 \%$, Oliec acid decreased by $31.8 \%$, linoliec acid decreased by $62.0 \%$. The effects of gamma irradiation doses and storage duration interaction on fatty acid composition of natural hazelnut kernels were not found to be significant $(p>0.05)$ (Koc et al., 2017).

Mahfouz, (2014)statedthatthe fatty acid profile slightly changed due to irradiation. The major change in fatty acid composition was the decrease in the quantity of fatty acids (C16:0, C18:0 and C18:1) and the increase in the quantity of fatty acid (C18:2).There were fluctuating changes (either increasing or decreasing) in fatty acids throughout the storage duration. 


\section{Ayat L. K. Soude, Hania F. G. El-Neily \\ And Ashraf A. Abd El-Megeid}

Biological analysis for rats feed on diet contain untreated and treated nuts:

The relative organs weight of rats feed on diet containing untreated and treated nuts with irradiation:

The data in table ( $5 \& 6$ ) showed the mean value of relative organs weight of rats fed on diets containing un-treated and treated almond and hazelnut with irradiation at dose of 6 and $10 \mathrm{kGy}$. The mean values of heart, liver, spleen, testes and kidney showed nonsignificant changes between the groups fed on diets containing untreated almonds or hazelnut, as compared to control group fed on basal diet. On the other hand, feeding rats on diet containing almonds or hazelnut, which treated with irradiation at dose (6 and 10 $k G y$ ), caused non-significant differences in all organs weights, as compared to the group fed on diet containing un-treated almond except heart and spleen in almonds \& spleen in hazelnut groups.

Effect of diet containing untreated and treated almond and hazelnutwith irradiation, onsome biochemical analysis of healthy rats.

\section{Almond:}

The table (7) showed that the mean values of hemoglobin, glucose and Alanin Amino Transferase ALT did not affect with diet containing untreated almonds, while Aspartate Amino Transferase AST increased significant, as compared to control group (fed on control diet). Treating almonds with irradiation at dose (6 kGy) showed non-significant changes in all parameters, except AST enzyme, as compared to the group fed on diet containing un-treated almonds. On the other hand, the high dose of irradiation of almonds 
Egyptian J. of Nutrition Vol. XXXIV No. 3 (2019)

led to significant increase in hemoglobin and glucose, as compared to the group fed on diet containing un-treated almonds

\section{Hazelnut:}

Un-treated hazelnut led to non-significant changes in glucose and AST enzyme, while caused significant decrease in hemoglobin and ALT enzyme were observed, as compared to the control group fed on basal diet. The data presented in Table (8) revealed that, treated hazelnut with (6 and $10 \mathrm{kGy}$ ) increased the mean value of hemoglobin significantly, while the other parameters showed nonsignificant changes, as compared to the control group fed on untreated hazelnut.

In this respect (Jiang et al., 2002) reported that, the Nurses' Health Study showed in 83,818 healthy women that eating $140 \mathrm{~g}$ of nuts per week was related to a significant lower DMT2-risk compared to non-consumers. This result was inter alia attributed to the low glycemic index of nuts and their high fiber and magnesium content. In addition, recent studies with 135,956 women confirmed an association between increased walnut consumption (> $56 \mathrm{~g} /$ week) and a lower incidence (15\%) for DMT2 (Pan and Manson 2013).Contrary to that, Kochar et al. (2010) observed no effect of nut consumption on the DMT2-risk in 20,224 male subjects of the Physician's Health Study.

The responsible mechanisms mediated by nut consumption which cause a reduction of the DMT2-riskare not yet fully understood. A modulation of the adiponectin concentration appears conceivable (Aronis et al., 2012).The protein, formed by fat-laden adipocytes, is involved in the regulation of appetite and inverse associated with the DMT2-risk (Heidemann et al., 2008). 


\section{Ayat L. K. Soude, Hania F. G. El-Neily \\ And Ashraf A. Abd El-Megeid}

It is also possible that an increase in insulin sensitivity results from the arginine and zinc content of the nuts, which stimulate both insulin secretion and the receptor tyrosine kinase and thereby increase the insulin sensitivity of the cells. In addition, a reduced postprandial glycemic response mediated by nut consumption and a significantly higher release of satiety hormones may also contribute to the prevention of DMT2 (Reis et al., 2012).

Nuts are highly nutritious foods rich in unsaturated fatty acids, fiber, vitamins, minerals and some bioactive substances, such as phenolic antioxidants and phytosterols(Bao et al., 2013 ) and due to these wholesome benefits, individuals living with liver disease are usually advised to include nuts in their diet (Han et al., 2014).

Wien et al., (2003)found that a hypocaloric, almond-enriched diet led to greater reduction in weight andbody mass index BMI. This study results were in accordance with the findings of most previous investigations in this field, supporting that weight loss through lifestyle modification, medication or bariatric surgery is associated with a decrease in liver enzymes (Wang et al., 2003, Straznicky et al., 2012 and Clark 2006).

The improvement in liver enzymes in treated diabetic rats with some nuts may be related to the antioxidant properties of these nuts, which have scavenge free radicals and thereby may protect cells from oxidative stress. Almonds (Amygdaluscommunis L.) are a rich source of nutrients and phytochemicals such as vitamin $E$ also polyphenols (Alasalvar et al., 2006 and Yang et al., 2009 )that is known as antioxidants and had strong free radical scavenging (Choi et al., 2002). 
Egyptian J. of Nutrition Vol. XXXIV No. 3 (2019)

Effect of diet containing untreated and treated almond and hazelnut with irradiationon lipid profile of healthy rats:

\section{Almond:}

Table (9) showed the levels of serum cholesterol, triacylglycerol's, high density lipoprotein-cholesterol HDL-C and low density lipoprotein-cholesterol LDL-c in serum rats which were fed on diets containing untreated almonds and treated almonds with irradiation at levels ( 6 and $10 \mathrm{kGy}$ ).

The data in this Table revealed that, feeding rats on diet containing untreated almond showed non-significant changes in the mean value of serum cholesterol and HDL-C, while serum LDL-C and triglyceride changed significantly, as compared to healthy rats fed on basal diet. The mean value of serum triacylglycerol's increased significantly in serumrats treated with untreated almonds, as compared to the control group.

Treating healthy rats with diets containing irradiated almond ( 6 and $10 \mathrm{kGy}$ ) led to non-significant differences in the mean values of serum cholesterol, triacylglycerol's, HDL-C and LDL-C, as compared to the group of rats fed on diet containing untreated almond. Increase the intake of monounsaturated fat in the diet has been associated with reduced susceptibility of LDL to oxidation(David et al., 2008), almonds consists of a number of components that may reduce LDL oxidation. On the other hand, (Jennifer et al. 2002)indicated that HDL cholesterol was significantly lower with the almond diets and suggested that nuts can reduce heart disease risk in healthy persons.

The National Cholesterol Education Program demonstrated that, almond consumption fits well with current American Heart 


\section{Ayat L. K. Soude, Hania F. G. El-Neily \\ And Ashraf A. Abd El-Megeid}

Association guidelines to replace saturated fats with unsaturated fats and with the National Cholesterol Education Program (NCEP) guidelines to liberalize total fat intake, specifically from monounsaturated fat (MUFA),(Garg et al., 1988) related to its ability to increase HDL cholesterol. Hyson et al., (2002) revealed that the consumption of almond kernels with or without brawn skin is effective in reducing the level of total cholesterol and LDL.

\section{Hazelnut:}

The result of lipid profile including (serum cholesterol, triglyceride, HDL-C and LDL-C) in healthy rats fed on basal diet, diet containing untreated hazelnut and diets containing irradiated hazelnut with (6 kGy and 10kGy) presented in Table (10) .

Feeding healthy rats on diet containing untreated hazelnut showed non-significant differences in serum cholesterol and HDL-C, as compared to healthy rats fed on basal diet. Untreated hazelnut caused significant increase in the mean value of triglycerides and significant decrease in LDL-c in healthy rats, as compared to healthy rats fed on basal diet. Treating healthy rats with irradiated hazelnut (6 and $10 \mathrm{kGy}$ ) recorded non-significant changes in total cholesterol, triglycerides, HDL-C and LDL-C, as compared to basil rats fed on untreated hazelnut, except LDL-c in the group treated with irradiation hazelnut with (10 kGy). In this respect, (Simone et al., 2016)who reported that Hazelnut-enriched diet is associated with a decrease of LDL and total cholesterol, while HDL cholesterol, triglycerides and body mass index (BMI) remain substantially unchanged. Mercanlıgilet al., (2007)reported that, hazelnut-enriched diet decreased the mean value of the ratios of total cholesterol/HDL cholesterol and LDL-c/HDL-c. 
Egyptian J. of Nutrition Vol. XXXIV No. 3 (2019)

The effect of untreated and treated nuts with irradiation on antioxidant enzymes inhealthy rats:

Important determinants of cellular antioxidant enzyme are the enzymes Sodium Oxide Dismutase (SOD), Catalase (CAT) and Glutathion Peroxidase (GPx), which are responsible for the elimination of Reactive Oxygen Species ROS. Because these enzymes act sequentially to remove ROS, the balance of the activity of these enzymes may be as critical in the defense against ROS as the activity of the enzymes alone (Boateng et al., 2016).

\section{Almond:}

Data in table (11) showed the effect of untreated and treated almonds with irradiation ( $6 \mathrm{kGy}$ and $10 \mathrm{kGy}$ ) on malonaldehyedand antioxidant enzymes of healthy rats. Feeding rats on diet containing untreated almonds showed significantdecrease in the mean value of malonaldehyed, while the other parameters recorded significant increase, as compared to control group. On the other hand treating rats with irradiationat doses (6 and $10 \mathrm{kGy}$ )showed non-significant changes in malonaldehyed, as compared to the group fed on diet containing untreatedalmond. On the other hand, the mean value of antioxidant enzymes including"catalase activity and superoxide dismutase activity in liver tissue" increased significantly in rats which treated with irradiated almonds, as compared to the control groups.

In this respect, Soheil et al., (2015)resulted that after treatment with almond hull, the serum level of MDA in all test groups significantly decreased. David et al., (2008) the full-dose almonds reduced serum Concentrations of malondialdehyde. Li et al., (2010) reported that feeding diabetic rats on diets containing irradiated almond with 6 and $10 \mathrm{kGy}$ showed non-significant differences in 


\section{Ayat L. K. Soude, Hania F. G. El-Neily \\ And Ashraf A. Abd El-Megeid}

malonaldehyed, as compared to the group fed on diet containing untreated almond.

\section{Hazelnut:}

Table (12) showed the effect of untreated and treated hazelnut with irradiation ( $6 \mathrm{kGy}$ and $10 \mathrm{kGy}$ ) on malonaldehyed and antioxidant enzymes of healthy rats. The mean valueof the malonaldehyeddecreased significantly in the groups treated with irradiated and un irradiated hazelnut, as compared to the control group.The mean values of GPX and SOD in healthy rats fed on diet containing untreated hazelnut showed non-significant changes, while catalase increased significantly, as compared to healthy rats fed on based diet.

Treated healthy groups with diets containing irradiated hazelnut with (6 and $10 \mathrm{kGy}$ ) showed non-significant differences in all antioxidant enzymes (Malonaldehyed, GPX, Catalase and SOD), as compared to the group of rats, which was fed on diet containing untreated hazelnut.

Aydan et al., (2004)indicate that hazelnut oil reduced oxidative stress and cholesterol accumulation in the aortas of rabbits fed on high cholesterol diet. 
Egyptian J. of Nutrition Vol. XXXIV No. 3 (2019)

(Table 1): Approximate analysis of un-treated and treated almonds with irradiation.

\begin{tabular}{c|c|c|c|c|c|c|c|c}
\hline \multirow{2}{*}{ Radiation } & \multicolumn{4}{|c}{ Zero time } & \multicolumn{4}{c}{ Storage (6 months) } \\
\cline { 2 - 9 } Dose kGy & $\begin{array}{c}\text { Moisture } \\
\mathrm{g} / 100 \mathrm{~g}\end{array}$ & $\begin{array}{c}\text { Ash } \\
\mathrm{g} / 100 \mathrm{~g}\end{array}$ & $\begin{array}{c}\text { Protein } \\
\mathrm{g} / 100 \mathrm{~g}\end{array}$ & $\begin{array}{c}\text { Lipid } \\
\mathrm{g} / 100 \mathrm{~g}\end{array}$ & $\begin{array}{c}\text { Moisture } \\
\mathrm{g} / 100 \mathrm{~g}\end{array}$ & $\begin{array}{c}\text { Ash } \\
\mathrm{g} / 100 \mathrm{~g}\end{array}$ & $\begin{array}{c}\text { Protein } \\
\mathrm{g} / 100 \mathrm{~g}\end{array}$ & $\begin{array}{c}\text { Lipid } \\
\mathrm{g} / 100 \mathrm{~g}\end{array}$ \\
\hline \multirow{2}{*}{ Control } & $\begin{array}{c}6.17^{\mathrm{a}} \\
\pm 0.186\end{array}$ & $\begin{array}{c}3.03^{\mathrm{a}} \\
\pm 0.03\end{array}$ & $\begin{array}{c}28.1^{\mathrm{a}} \\
\pm 0.12\end{array}$ & $\begin{array}{c}52.4^{\mathrm{a}} \\
\pm 0.2\end{array}$ & $\begin{array}{c}6.53^{\mathrm{a}} \\
\pm 3.274\end{array}$ & $\begin{array}{c}4.36^{\mathrm{a}} \\
\pm 0.0\end{array}$ & $\begin{array}{c}23.5^{\mathrm{a}} \\
\pm 0.12\end{array}$ & $\begin{array}{c}54.6 \\
\mathrm{a}\end{array}$ \\
\hline \multirow{2}{*}{$6 \mathrm{kGy}$} & $\begin{array}{c}5.99^{\mathrm{a}} \\
\pm 0.521\end{array}$ & $\begin{array}{c}2.83^{\mathrm{b}} \\
\pm 0.03\end{array}$ & $\begin{array}{c}28.7^{\mathrm{a}} \\
\pm 0.15\end{array}$ & $\begin{array}{c}54.2^{\mathrm{a}} \\
\pm 4.8\end{array}$ & $\begin{array}{c}6.28^{\mathrm{a}} \\
\pm 0.643\end{array}$ & $\begin{array}{c}4.46^{\mathrm{a}} \\
\pm 1.6\end{array}$ & $\begin{array}{c}22.3^{\mathrm{a}} \\
\pm 0.15\end{array}$ & $\begin{array}{c}54.2 \\
\mathrm{a}\end{array}$ \\
\hline \multirow{2}{*}{$10 \mathrm{kGy}$} & $\begin{array}{c}5.26^{\mathrm{b}} \\
\pm 0.066\end{array}$ & $\begin{array}{c}2.73^{\mathrm{b}} \\
\pm 0.09\end{array}$ & $\begin{array}{c}27.5^{\mathrm{a}} \\
\pm 0.12\end{array}$ & $\begin{array}{c}52.9^{\mathrm{a}} \\
\pm 0.7\end{array}$ & $\begin{array}{c}6.52^{\mathrm{a}} \\
\pm 1.574\end{array}$ & $\begin{array}{c}4.30^{\mathrm{a}} \\
\pm 0.5\end{array}$ & $\begin{array}{c}21.90^{\mathrm{a}} \\
\pm 0.12\end{array}$ & $\begin{array}{c}54.1 \\
\mathrm{a}\end{array}$ \\
\hline
\end{tabular}

*Data represented mean \pm standard error.

*Values at the same column with different letters are significant at $P<0.05$.

(Table 2): Approximate analysis of un-treated and treated hazelnut with irradiation.

\begin{tabular}{r|c|c|c|c|c|c|c|c}
\hline \multirow{2}{*}{ Radiation } & \multicolumn{4}{|c|}{ Zero time } & \multicolumn{4}{c}{ Storage (6 months) } \\
\cline { 2 - 9 } Dose kGy & Moisture & Ash & Protein & Lipid & Moisture & Ash & Protein & Lipid \\
$\mathrm{g} / 100 \mathrm{~g}$ & $\mathrm{~g} / 100 \mathrm{~g}$ & $\mathrm{~g} / 100 \mathrm{~g}$ & $\mathrm{~g} / 100 \mathrm{~g}$ & $\mathrm{~g} / 100 \mathrm{~g}$ & $\mathrm{~g} / 100 \mathrm{~g}$ & $\mathrm{~g} / 100 \mathrm{~g}$ & $\mathrm{~g} / 100 \mathrm{~g}$ \\
\hline \multirow{2}{*}{ Control } & $4.73^{\mathrm{a}}$ & $2.33^{\mathrm{a}}$ & $15.00^{\mathrm{a}}$ & $62.49^{\mathrm{a}}$ & $14.60^{\mathrm{b}}$ & $2.53^{\mathrm{a}}$ & $21.00^{\mathrm{a}}$ & $56.96^{\mathrm{a}}$ \\
& \pm 0.176 & \pm 0.06 & \pm 0.12 & \pm 0.499 & \pm 0.200 & \pm 0.033 & \pm 0.12 & \pm 3.996 \\
\hline \multirow{2}{*}{$6 \mathrm{kGy}$} & $4.20^{\mathrm{b}}$ & $1.83^{\mathrm{a}}$ & $15.20^{\mathrm{a}}$ & $59.07^{\mathrm{b}}$ & $15.13^{\mathrm{b}}$ & $2.03^{\mathrm{a}}$ & $19.90^{\mathrm{a}}$ & $54.80^{\mathrm{a}}$ \\
& \pm 0.058 & \pm 0.328 & \pm 0.15 & \pm 0.067 & \pm 0.570 & \pm 0.333 & \pm 0.14 & \pm 3.468 \\
\hline \multirow{2}{*}{$10 \mathrm{kGy}$} & $4.10^{\mathrm{b}}$ & $1.71^{\mathrm{a}}$ & $16.80^{\mathrm{a}}$ & $58.13^{\mathrm{b}}$ & $16.70^{\mathrm{a}}$ & $2.10^{\mathrm{a}}$ & $20.10^{\mathrm{a}}$ & $51.56^{\mathrm{a}}$ \\
& \pm 0.100 & \pm 0.00 & \pm 0.12 & \pm 1.10 & \pm 0.058 & \pm 0.05 & \pm 0.15 & \pm 1.14 \\
\hline
\end{tabular}

* Data represented mean \pm standard error.

*Values at the same column with different letters are significant at $\mathrm{P}<0.05$. 


\section{Ayat L. K. Soude, Hania F. G. El-Neily}

\section{And Ashraf A. Abd El-Megeid}

Table (3): The percentage of fatty acids in control and irradiated almond at zero time and after storage for 6 months.

\begin{tabular}{l|c|c|c|c|c|c}
\hline \multicolumn{7}{c}{ Almond at Zero time } \\
\hline Fatty acid & Carbon no. & control & 6 kGy & Change\% & $10 \mathrm{kGy}$ & Change\% \\
\hline Palmitic acid & C 16:0 & 7.42 & 7.6 & +2.4 & 9.5 & +28.0 \\
\hline Oleic acid & C 18:1 & 73.74 & 66.6 & -9.68 & 71.7 & -2.7 \\
\hline Linoliec & C 18:2 & 18.8 & 25.69 & +36.64 & 14.7 & -21.8 \\
\hline \multicolumn{7}{|c|}{ Almond after storage for six months } \\
\hline Palmitic acid & C 16:0 & 10.6 & 12.05 & +13.6 & 14.2 & +33.96 \\
\hline Oleic acid & C 18:1 & 76.42 & 68.40 & -10.49 & 57.9 & -24.23 \\
\hline Linoliec & C 18:2 & - & - & - & - & - \\
\hline Arachidic & C20:0 & 3.57 & 2.6 & -27.1 & 4.8 & +34.45 \\
\hline
\end{tabular}

Table (4): The percentage of fatty acids in control and irradiated Hazelnut at zero time and after storage for 6 months.

\begin{tabular}{l|c|c|c|c|c|c}
\hline \multicolumn{7}{c}{ Hazelnut at zero time } \\
\hline Fatty acid & $\begin{array}{c}\text { Carbon } \\
\text { no. }\end{array}$ & control & 6 kGy & Change\% & 10 kGy & Change\% \\
\hline Palmitic acid & C 16:0 & 6.58 & 6.00 & -8.8 & 6.98 & +6.0 \\
\hline Oleic acid & C 18:1 & 81.28 & 74.3 & -8.5 & 79.61 & -2.0 \\
\hline Linoliec & C 18:2 & 8.19 & 7.6 & -3.6 & 7.7 & -5.9 \\
\hline \multicolumn{7}{c}{ Hazelnut after storage for six months } \\
\hline Palmitic acid & C 16:0 & 5.9 & 10.2 & +72 & 4.7 & -20.3 \\
\hline Oleic acid & C 18:1 & 79.71 & 78.0 & -2.1 & 54.3 & -31.8 \\
\hline Linoliec & C 18:2 & 8.3 & - & - & 3.1 & -62.0 \\
\hline Arachidic & C20:0 & - & 2.4 & & - & \\
\hline
\end{tabular}


Egyptian J. of Nutrition Vol. XXXIV No. 3 (2019)

Table (5): Relative organs weight of rats fed on diet containing untreated and treated almond with irradiation.

\begin{tabular}{|c|c|c|c|c|c|c|}
\hline \multirow{2}{*}{\multicolumn{2}{|c|}{$\mathrm{C}_{\text {Groups }}$ Organs }} & \multicolumn{5}{|c|}{ Organs weight / body weight \% } \\
\hline & & Heart & Liver & Spleen & Testes & Kidney \\
\hline \multirow{2}{*}{\multicolumn{2}{|c|}{ Basil diet }} & $0.7^{\mathrm{a}}$ & $5.02^{\mathrm{a}}$ & $0.56^{\mathrm{b}}$ & $1.34^{b}$ & $1.13^{a}$ \\
\hline & & \pm 0.01 & \pm 0.14 & \pm 0.04 & \pm 0.08 & \pm 0.07 \\
\hline \multirow{2}{*}{\multicolumn{2}{|c|}{ Un-treated almond }} & $0.68^{a}$ & $4.79^{a}$ & $0.67^{\mathrm{ab}}$ & $1.83^{\mathrm{a}}$ & $1.13^{\mathrm{a}}$ \\
\hline & & \pm 0.09 & \pm 0.48 & \pm 0.11 & \pm 0.20 & \pm 0.09 \\
\hline \multirow{4}{*}{ 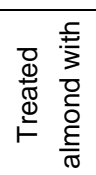 } & $6 \mathrm{KG}$ & $0.79^{b}$ & $4.77^{a}$ & $0.61^{b}$ & $1.86^{\mathrm{a}}$ & $1.13^{\mathrm{a}}$ \\
\hline & o nGy & \pm 0.08 & \pm 0.37 & \pm 0.06 & \pm 0.07 & \pm 0.03 \\
\hline & 10 & $0.77^{b}$ & $5.11^{\mathrm{a}}$ & $0.91^{c}$ & $1.88^{\mathrm{a}}$ & $1.13^{\mathrm{a}}$ \\
\hline & KGy & 0.09 & \pm 0.60 & \pm 0.10 & \pm 0.21 & \pm 0.19 \\
\hline & P. Value & 0.0001 & 0.0001 & 0.0001 & 0.0001 & 0.0001 \\
\hline
\end{tabular}

${ }^{*}$ Values are expressed as means \pm SD.

*Values at the same column with different letters are significant at $\mathrm{P}<0.05$.

Table (6): Relative organs weight of rats fed on diet containing untreated and treated hazelnut with irradiation.

\begin{tabular}{|c|c|c|c|c|c|c|}
\hline \multirow{2}{*}{\multicolumn{2}{|c|}{$\mathrm{Cr}_{\text {Groups }}$ Organs }} & \multicolumn{5}{|c|}{ Organs weight / body weight \% } \\
\hline & & Heart & Liver & Spleen & Testes & Kidney \\
\hline \multirow{2}{*}{\multicolumn{2}{|c|}{ Basil diet }} & $0.70^{\mathrm{a}}$ & $5.0^{\mathrm{a}}$ & $0.56^{a}$ & $1.34^{\mathrm{b}}$ & $1.13^{a}$ \\
\hline & & \pm 0.01 & \pm 0.14 & \pm 0.04 & \pm 0.08 & \pm 0.07 \\
\hline \multirow{2}{*}{\multicolumn{2}{|c|}{$\begin{array}{l}\text { Untreated } \\
\text { hazelnut }\end{array}$}} & $0.7^{\mathrm{a}}$ & $4.47^{a}$ & $1.05^{b}$ & $1.74^{\mathrm{a}}$ & $1.25^{\mathrm{a}}$ \\
\hline & & \pm 0.09 & \pm 0.57 & \pm 0.21 & \pm 0.16 & \pm 0.18 \\
\hline \multirow{4}{*}{ 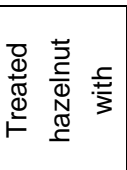 } & \multirow{2}{*}{6 KGy } & $0.71^{a}$ & $4.95^{a}$ & $0.98^{\mathrm{ab}}$ & $1.79^{a}$ & $1.38^{a}$ \\
\hline & & \pm 0.08 & \pm 0.46 & \pm 0.06 & \pm 0.20 & \pm 0.12 \\
\hline & \multirow{2}{*}{$10 K G y$} & $0.65^{a}$ & $4.70^{\mathrm{a}}$ & $0.82^{\mathrm{c}}$ & $1.68^{a}$ & $1.39^{\mathrm{a}}$ \\
\hline & & \pm 0.07 & \pm 0.44 & \pm 0.12 & \pm 0.14 & \pm 0.12 \\
\hline \multicolumn{2}{|c|}{ P.Value } & 0.0001 & 0.0001 & 0.0001 & 0.0001 & 0.0001 \\
\hline
\end{tabular}

${ }^{*}$ Values are expressed as means \pm SD.

*Values at the same column with different letters are significant at $P<0.05$. 


\section{Ayat L. K. Soude, Hania F. G. El-Neily}

\section{And Ashraf A. Abd El-Megeid}

Table (7): Effect of diet containing untreated and treated almond with irradiation on blood hemoglobin, serum glucose and liver enzymes of healthy rats.

\begin{tabular}{|c|c|c|c|c|c|}
\hline \multicolumn{2}{|c|}{ groups } & $\begin{array}{l}\text { Hemoglobin } \\
\text { g/dl }\end{array}$ & $\begin{array}{c}\text { Glucose } \\
\mathrm{mg} / \mathrm{dl}\end{array}$ & $\begin{array}{l}\text { AST } \\
U / L\end{array}$ & $\begin{array}{l}\mathrm{ALT} \\
\mathrm{U} / \mathrm{L}\end{array}$ \\
\hline \multicolumn{2}{|l|}{ Basil diet } & $\begin{array}{c}15.73^{\mathrm{a}} \\
\pm 1.5\end{array}$ & $\begin{array}{c}74.22^{\mathrm{a}} \\
\pm 7.0\end{array}$ & $\begin{array}{c}83.75^{\mathrm{ab}} \\
\pm 7.3\end{array}$ & $\begin{array}{l}22.16^{\mathrm{b}} \\
\pm 1.10\end{array}$ \\
\hline \multicolumn{2}{|c|}{ Untreated almond } & $\begin{array}{l}15.72^{\mathrm{a}} \\
\pm 0.84\end{array}$ & $\begin{array}{c}83.46^{\mathrm{ab}} \\
\pm 5.3\end{array}$ & $\begin{array}{c}94.00^{\mathrm{c}} \\
\pm 0\end{array}$ & $\begin{array}{l}26.83^{\mathrm{ab}} \\
\pm 0.83\end{array}$ \\
\hline \multirow{2}{*}{ 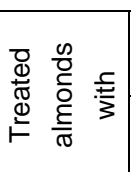 } & 6 kGy & $\begin{array}{l}14.10^{\mathrm{a}} \\
\pm 1.46\end{array}$ & $\begin{array}{c}73.87^{\mathrm{a}} \\
\pm 5.4\end{array}$ & $\begin{array}{l}89.16^{\mathrm{a}} \\
\pm 3.08\end{array}$ & $\begin{array}{l}26.00^{\mathrm{a}} \\
\pm 0.110\end{array}$ \\
\hline & 10 kGy & $\begin{array}{l}16.90^{\mathrm{c}} \\
\pm 3.87\end{array}$ & $\begin{array}{l}91.38^{c} \\
\pm 14.36\end{array}$ & $\begin{array}{l}88.80^{\mathrm{a}} \\
\pm 3.32\end{array}$ & $\begin{array}{l}26.00^{\mathrm{a}} \\
\pm 0.042\end{array}$ \\
\hline \multicolumn{2}{|c|}{ PV } & 0.8515 & 0.4517 & 0.3165 & 0.0014 \\
\hline
\end{tabular}

*Values are expressed as means \pm SD.

*Values at the same column with different letters are significant at $\mathrm{P}<0.05$.

Table (8): Effect of diets containing untreated and treated hazelnut with irradiation on blood hemoglobin, serum glucose and liver enzymes of healthy rats.

\begin{tabular}{|c|c|c|c|c|c|}
\hline \multicolumn{2}{|c|}{ groups } & $\begin{array}{c}\text { Hemoglobin } \\
\mathrm{g} / \mathrm{l}\end{array}$ & $\begin{array}{c}\text { Glucose } \\
\mathrm{mg} / \mathrm{l}\end{array}$ & $\begin{array}{l}\text { AST } \\
\text { U/L }\end{array}$ & $\begin{array}{l}\mathrm{ALT} \\
\mathrm{U} / \mathrm{L}\end{array}$ \\
\hline \multicolumn{2}{|l|}{ Basil diet } & $\begin{array}{c}15.73^{\mathrm{b}} \\
\pm 1.5\end{array}$ & $\begin{array}{c}74.22^{\mathrm{a}} \\
\pm 7.0\end{array}$ & $\begin{array}{c}83.75^{\mathrm{a}} \\
\pm 7.3\end{array}$ & $\begin{array}{l}22.16^{\mathrm{a}} \\
\pm 1.10\end{array}$ \\
\hline \multicolumn{2}{|c|}{ Untreated hazelnut } & $\begin{array}{l}13.17^{\mathrm{C}} \\
\pm 1.03\end{array}$ & $\begin{array}{c}80.51^{\mathrm{ab}} \\
\pm 6.17\end{array}$ & $\begin{array}{l}94.00^{\mathrm{a}} \\
\pm 0\end{array}$ & $\begin{array}{l}13.83^{b} \\
\pm 0.94\end{array}$ \\
\hline \multirow{2}{*}{ 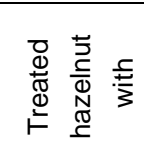 } & 6 kGy & $\begin{array}{l}16.59^{\mathrm{a}} \\
\pm 1.51\end{array}$ & $\begin{array}{l}72.72^{\mathrm{ab}} \\
\pm 16.03\end{array}$ & $\begin{array}{l}94.00^{\mathrm{a}} \\
\pm 1.11\end{array}$ & $\begin{array}{l}16.00^{\mathrm{ab}} \\
\pm 0.81\end{array}$ \\
\hline & $\begin{array}{c}10 \\
k G y\end{array}$ & $\begin{array}{l}16.68^{\mathrm{a}} \\
\pm 1.71\end{array}$ & $\begin{array}{l}78.34^{\mathrm{ac}} \\
\pm 3.03\end{array}$ & $\begin{array}{l}94.00^{\mathrm{a}} \\
\pm 0\end{array}$ & $\begin{array}{l}15.00^{\mathrm{b}} \\
\pm 1.09\end{array}$ \\
\hline \multicolumn{2}{|c|}{ PV } & 0.326 & 0.932 & 0.179 & 0.0065 \\
\hline
\end{tabular}

*Values are expressed as means \pm SD.

*Values at the same column with different letters are significant at $\mathrm{P}<0.05$. 
Egyptian J. of Nutrition Vol. XXXIV No. 3 (2019)

Table (9): Effect of diet containing untreated and treated almond with irradiation on lipid profile of healthy rats.

\begin{tabular}{|c|c|c|c|c|c|}
\hline \multicolumn{2}{|c|}{ Groups } & $\begin{array}{c}\text { Cholesterol } \\
\mathrm{mg} / \mathrm{dl}\end{array}$ & $\begin{array}{c}\text { Triacylglycerol } \\
\mathrm{mg} / \mathrm{dl}\end{array}$ & $\begin{array}{l}\mathrm{HDL}-\mathrm{c} \\
\mathrm{mg} / \mathrm{dl}\end{array}$ & $\begin{array}{l}\text { LDL-c } \\
\mathrm{mg} / \mathrm{dl}\end{array}$ \\
\hline \multicolumn{2}{|l|}{ Basil diet } & $\begin{array}{l}139.00^{\mathrm{b}} \\
\pm 4.35\end{array}$ & $\begin{array}{l}79.37^{a} \\
\pm 17.18\end{array}$ & $\begin{array}{l}61.56^{\mathrm{a}} \\
\pm 1.14\end{array}$ & $\begin{array}{l}61.57^{a} \\
\pm 7.10\end{array}$ \\
\hline \multicolumn{2}{|c|}{ Untreated almond } & $\begin{array}{c}138.33^{\mathrm{ab}} \\
\pm 7.53\end{array}$ & $\begin{array}{c}155.66^{\mathrm{b}} \\
\pm 4.70\end{array}$ & $\begin{array}{l}63.46^{a} \\
\pm 0.50\end{array}$ & $\begin{array}{l}44.70^{\mathrm{b}} \\
\pm 7.77\end{array}$ \\
\hline \multirow{2}{*}{ 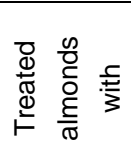 } & 6 kGy & $\begin{array}{c}135.00^{\mathrm{a}} \\
\pm 3.57\end{array}$ & $\begin{array}{c}149.00^{\mathrm{b}} \\
\pm 6.80\end{array}$ & $\begin{array}{l}61.64^{\mathrm{a}} \\
\pm 1.43\end{array}$ & $\begin{array}{l}44.64^{\mathrm{b}} \\
\pm 0.27\end{array}$ \\
\hline & $10 \mathrm{kGy}$ & $\begin{array}{c}135.33^{a} \\
\pm 1.66\end{array}$ & $\begin{array}{l}146.66^{b} \\
\pm 25.71\end{array}$ & $\begin{array}{l}61.75^{a} \\
\pm 1.81\end{array}$ & $\begin{array}{l}44.25^{\mathrm{b}} \\
\pm 4.54\end{array}$ \\
\hline
\end{tabular}

*Values are expressed as means \pm SD.

*Values at the same column with different letters are significant at $\mathrm{P}<0.05$.

Table (10): Effect of diet containing untreated and treated hazelnut with irradiation on lipid profile of healthy rats.

\begin{tabular}{|c|c|c|c|c|c|}
\hline \multicolumn{2}{|c|}{ Groups } & $\begin{array}{c}\text { Cholesterol } \\
\mathrm{mg} / \mathrm{dl}\end{array}$ & $\begin{array}{c}\text { Triacylglycerol } \\
\mathrm{mg} / \mathrm{dl}\end{array}$ & $\begin{array}{l}\mathrm{HDL-c} \\
\mathrm{mg} / \mathrm{dl}\end{array}$ & $\begin{array}{l}\text { LDL-c } \\
\mathrm{mg} / \mathrm{dl}\end{array}$ \\
\hline \multicolumn{2}{|l|}{ Basil diet } & $\begin{array}{r}139^{\mathrm{b}} \\
\pm 4.35\end{array}$ & $\begin{array}{l}79.33^{c} \\
\pm 17.18\end{array}$ & $\begin{array}{l}61.56^{\mathrm{a}} \\
\pm 1.14\end{array}$ & $\begin{array}{l}61.57^{c} \\
\pm 7.10\end{array}$ \\
\hline \multicolumn{2}{|c|}{$\begin{array}{l}\text { Untreated } \\
\text { hazelnut }\end{array}$} & $\begin{array}{c}133.33^{a b} \\
\pm 11.78\end{array}$ & $\begin{array}{l}149.66^{a} \\
\pm 15.34\end{array}$ & $\begin{array}{l}60.42^{\mathrm{a}} \\
\pm 0.23\end{array}$ & $\begin{array}{l}38.98^{a} \\
\pm 8.83\end{array}$ \\
\hline \multirow{2}{*}{ 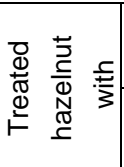 } & 6 kGy & $\begin{array}{c}131.33^{\mathrm{a}} \\
\pm 4.66\end{array}$ & $\begin{array}{c}161.33^{\mathrm{ab}} \\
\pm 8.29\end{array}$ & $\begin{array}{l}60.61^{\mathrm{a}} \\
\pm 0.77\end{array}$ & $\begin{array}{l}37.45^{\mathrm{a}} \\
\pm 4.36\end{array}$ \\
\hline & 10 kGy & $\begin{array}{c}131.00^{\mathrm{a}} \\
\pm 00\end{array}$ & $\begin{array}{c}172.66^{\mathrm{ab}} \\
\pm 5.84\end{array}$ & $\begin{array}{l}60.99^{\mathrm{a}} \\
\pm 0.87\end{array}$ & $\begin{array}{l}45.47^{b} \\
\pm 1.64\end{array}$ \\
\hline
\end{tabular}

*Values are expressed as means \pm SD.

*Values at the same column with different letters are significant at $\mathrm{P}<0.05$. 


\section{Ayat L. K. Soude, Hania F. G. El-Neily}

\section{And Ashraf A. Abd El-Megeid}

Table (11): Effect of diet containing untreated and treated almond with irradiation on malonaldehyed and antioxidant enzymes of healthy rats.

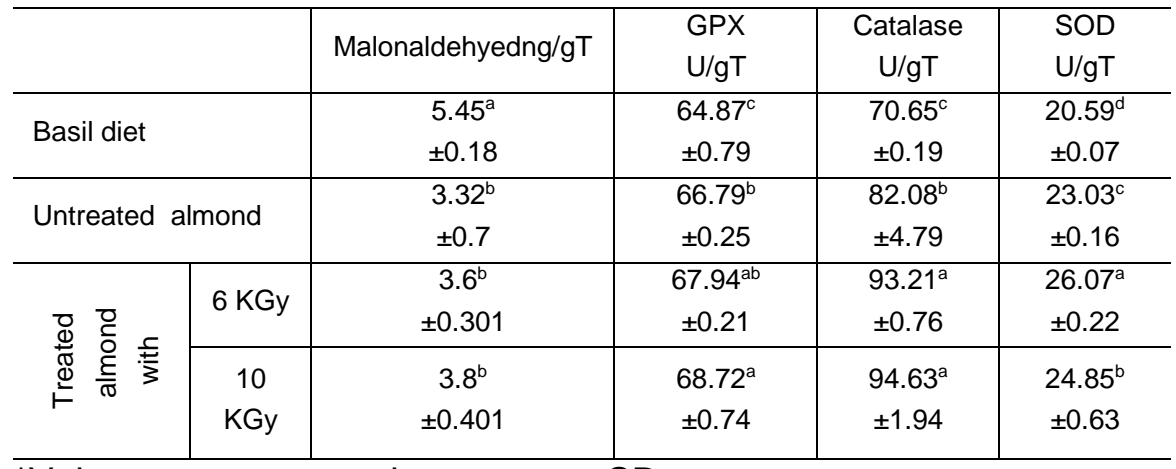

*Values are expressed as means \pm SD.

${ }^{*}$ Values at the same column with different letters are significant at $\mathrm{P}<0.05$.

Table (12): Effect of diet containing untreated and treated hazelnut on antioxidant enzymes of healthy rats.

\begin{tabular}{|c|c|c|c|c|c|}
\hline & & Malonaldehyedng/gT & $\begin{array}{l}\text { GPX } \\
\text { U/gT }\end{array}$ & $\begin{array}{c}\text { Catalase } \\
\mathrm{U} / \mathrm{gT}\end{array}$ & $\begin{array}{l}\text { SOD } \\
U / g T\end{array}$ \\
\hline \multicolumn{2}{|l|}{ Basil diet } & $5.45^{\mathrm{a}} \pm 0.18$ & $\begin{array}{l}64.87^{b} \\
\pm 0.49\end{array}$ & $\begin{array}{r}70.65^{c} \\
\pm 0.19\end{array}$ & $\begin{array}{r}20.59^{b} \\
\pm 0.07\end{array}$ \\
\hline \multicolumn{2}{|l|}{$\begin{array}{l}\text { Untreated } \\
\text { hazelnut }\end{array}$} & $4.65^{b} \pm 0.75$ & $\begin{array}{c}65.70^{\mathrm{ab}} \\
\pm 1.27\end{array}$ & $\begin{array}{c}95.89^{\mathrm{ab}} \\
\pm 6.04\end{array}$ & $\begin{array}{r}21.93^{\mathrm{ab}} \\
\pm 1.12\end{array}$ \\
\hline \multirow{2}{*}{ 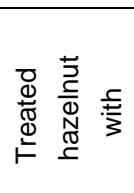 } & $\begin{array}{c}6 \\
\text { KGy }\end{array}$ & $4.65^{b} \pm 0.50$ & $\begin{array}{c}66.72^{\mathrm{ab}} \\
\pm 0.77\end{array}$ & $\begin{array}{c}105.11^{\mathrm{ab}} \\
\pm 3.25\end{array}$ & $\begin{array}{r}22.47^{a} \\
\pm 0.25\end{array}$ \\
\hline & $\begin{array}{c}10 \\
\text { KGy }\end{array}$ & $4.64^{b} \pm 0.311$ & $\begin{array}{l}71.32^{a} \\
\pm 3.26\end{array}$ & $\begin{array}{r}110.76^{\mathrm{a}} \\
\pm 0.93\end{array}$ & $\begin{array}{r}22.70^{\mathrm{a}} \\
\pm 0.16\end{array}$ \\
\hline
\end{tabular}

${ }^{*}$ Values are expressed as means \pm SD.

*Values at the same column with different letters are significant at $\mathrm{P}<0.05$. 
Egyptian J. of Nutrition Vol. XXXIV No. 3 (2019)

\section{References}

Aebi,H. (1984):

Determination of Catalase.MethodEnzymol 105, 121-126.

Akpabio, U. D. (2012):

Evaluation of proximate composition, mineral element and anti- nutrient in almond (Terminaliacatappa) seeds. Advances in Applied Science Research, 3 (4):2247-2252.

Alasalvar, C., Amaral, J. S. and Shahidi, F. (2006):

Functional Lipid Characteristics of Turkish Tombul Hazelnut. Journal Agricultural. Food Chemistry, 54: 10177-10183.

Alasalvar, C.; Amaral, J.S.; Sayir, G.; Shahidi, F.; (2009):

Lipid characteristics and essential minerals of native Turkish hazelnut varieties (CorylusavellanaL.). Food Chemistry. 113, 919-925.

Alison,K. and Oliver, C. C.-Y. (2012):

Health Benefits of Almonds beyond Cholesterol Reduction. . Journal Agricultural. Food Chemistry .60, 6694-6702.

Antonio, AL.; Carocho, M.; Bento, A.; Quintana, B.; Luisa Botelho, M.; Ferreira IC (2012):

Effects of gamma radiation on the biological, physicochemical, nutritional and antioxidant parameters of chestnutsA review. Food Chemistry Toxicol; 50:3234-3242. 


\section{Ayat L. K. Soude, Hania F. G. El-Neily \\ And Ashraf A. Abd El-Megeid}

A.O.A.C. (2003):

Association of Official Analytical Chemists International $18^{\text {th }}$ ed., Arlington, Virginia, USA.

Aronis, K.N.;Vamvinia, M.T. andChamberlanda, J.P. (2012):

Short-term walnut consumption increases circulating total adiponectin and apolipoprotein A concentrations, but does not affect markers of inflammation or vascular injury in obese humans with the metabolic syndrome: data from a doubleblinded, randomized, placebo-controlled study. Metabolism 61: 577-582.

Aronson,W. J.;Glaspy, J. A.; Reddy, S. T.; Reese, D.; Heber, D. and Bagga,D.(2001):

Modulation of Omega-3/Omega-6 Polyunsaturated Ratios with Dietary Fish Oils in Men with Prostate Cancer," Urology, 58(2): 283-288.

Ayca, D.; Galip, S. and Feride, S. (2007):

FTIR spectroscopic characterization of irradiated hazelnut (Corylusavellana L.) Food Chemistry 100.1106-1114. 
Egyptian J. of Nutrition Vol. XXXIV No. 3 (2019)

Aydan, H; Oznur, K.; Jale, B.; Mutlu, K.; Ugur. C.; Aykac-toker, G.; Hakan, B.; and Mujdat, U. (2004):

Hazelnut Oil Administration Reduces Aortic Cholesterol Accumulation and Lipid Peroxides in the Plasma, Liver, and Aorta of Rabbits Fed a High-cholesterol Diet. Bioscience.Biotechnology. Biochemistry,68(10), 2050-2057.

Bao, Y.; Han, J.; Hu, F.B.;Giovannucci, E.L.;Stampfer, M.J. and Willett, W,C.(2013):

Association of nut consumption with total and cause-specific mortality. The New England Journal of Medicine;369(21):2001-11.

Behgar, M.;Ghasemi, S.; Naserian, A.; Borzoie, A.; Fatollahi, H. (2011):

Gamma radiation effects on phenolics, antioxidants activity and in vitro digestion of pistachio (Pistachiavera) hull. RadiatPhysics Chemistry;80:963-967.

Bela, P.S.;Egeaa, I.;Romojaroa, F.;Concepcio, M. and Madrid, M. (2008):

Sensorial and chemical quality of electron beam irradiated almonds (Prunusamygdalus). Lebensmittel-Wissenschaft und -Technologie, 41, 442- 449. 


\section{Ayat L. K. Soude, Hania F. G. El-Neily \\ And Ashraf A. Abd El-Megeid}

Bhatti, I.A.; Iqbal, M.; Anwar, F.; Shahid, S.A. and Shahid, M. (2013):

Quality characteristics and microbiological safety evaluation of oils extracted from gamma irradiated almond (PrunusdulcisMill.) seeds. GrasasAceites, 64-72, 1.

Boateng, J.; Willis, S.; Busambwa, K.; Shackelford, L. and Verghese, M. (2016):

Modifying Effects of Pistachio Nuts on Antioxidant Enzymes in Azoxymethane (AOM) - induced Formation of Aberrant Crypt Foci. Internationaljournalcancer Recerch. 12 (3-4):140-151.

Choi, C.W.; Kim, S.C.; Hwang, S.S.; Choi, B.K.; Ahn, H.J.;Lee, M.Y.; Park, S.H. and Kim, S.K. (2002):

Antioxidant activity and free radical scavenging capacity between Korean medicinal plants and flavonoids by assayguided comparison. Plant Scince., 163: 1161-1168.

Clark, J.M. (2006):

Weight loss as a treatment for nonalcoholic fatty liver disease. JournalClinGastroenterol.40Suppl 1:S39-43.

Connor,W. E. (2000):

Importance of n-3 Fatty Acids in Health and Disease,.American Journal of Clinical Nutrition, 71(1): 171S$175 S$. 
Egyptian J. of Nutrition Vol. XXXIV No. 3 (2019)

Dacia, J.V. and Lewis S.M. (1985):

Practical Haematology. Churchill, Livingstone, ED. binburgh, London and NY, 5th ed.

David, J. A.; Jenkins, M.; Cyril, W. C. K.; Augustine, M.; Andrea, R. J.; Tri, H. N.; Dorothea; A. F.; Karen, G. L., and Jeffrey, B. (2008):

Almonds Reduce Biomarkers of Lipid Peroxidation in Older Hyperlipidemic Subjects . Journal of Nutrition. 138: 908-913.

Diehl, F. (1981):

Effects of combination processes on the nutritive value of food. Combination Processes in the Food Irradiation. International Atomic Agency, Vienna, Austria. pp. 349-366.

Duncan, D. B. (1955):

Multiple range test and multiple F-test. Biometrica 11:1.

Farkas, J. and Mohacsi-Farkas C. (2011):

History and future of food irradiation. Trends Food ScienceTechnolgy. 22:121-126.

Firdewald, W.T. (1972):

Estimation of concentration of Iwo-denisty lipoprotein cholesterol in plasma, without use of preparative ultracentrifuge. Clinical.Chemistry. 18 (6):499-502. 


\section{Ayat L. K. Soude, Hania F. G. El-Neily \\ And Ashraf A. Abd El-Megeid}

Garg, A.; Bonanome, A. and Grundy, S. M. (1988):

Comparison of a high carbohydrate diet with a highmonounsaturated-fat diet in patients with non-insulindependent diabetes mellitus. The New England Journal of Medicine. 319: 829-834.

\section{Haiwen Li and John W. Parry (2011):}

Phytochemical Compositions, Antioxidant Properties, and Colon Cancer Antiproliferation Effects of Turkish and Oregon Hazelnut.Food and Nutrition Sciences, 2:1142-1149.

Hamilton, R. J. and Hamilton, S. (1993):

Lipid Analysis a Practical Approach. IRL press, Oxford University Press, Oxford.

Han, J.M.; Jo, A.N.; Lee, S.M.; Bae, H.S.; Jun, D.W. and Cho, Y.K. (2014):

Associations between intakes of individual nutrients or whole food groups and non-alcoholic fatty liver disease among Korean adults. JournalGastroenterolHepatol.; 29(6):1265-72.

Harrison, K. and Were, L.; (2007):

Effect of gamma irradiation on total phenolic content yield and antioxidant capacity of almond skin extracts. Food Chemistry;102:932-937. 
Egyptian J. of Nutrition Vol. XXXIV No. 3 (2019)

Hegested, D.M.; Mills, C.; Elvehjem, C.A. and Hart, E.B. (1941):

Choline in the nutrition of the chicks. Journal Biological Chemistry, 138:459-470.

Heidemann, C.; Sun, Q. and van Dam, R.M. (2008).

Total and high-molecular-weight adiponectin and resistin in relation to the risk for type 2 diabetes in women. Annals of Internal Medicine149: 307-316.

Hyson, D.; Schneeman, B.O.; and Davis, P.A. (2002):

Almonds and almond oil have similar effects on plasma lipids and LDL oxidation in healthy men and women. Journal of Nutrition 132: 703-707.

Iso,H.; Sato,S.;Umemura, U.; Kudo, M.; Koike,K.; Kitamura,A.;Imano,H.; Okamura, T.; Naito, Y. and Shimamoto, T. (2002):

Linoleic Acid, Other Fatty Acids, and the Risk of Stroke," Stroke, 33: 2086-2093.

Jahanban, E. A;Jamei, R andJahanban, E.R (2010):

The importance of almond (PrunusamygdalusL.) and its byproducts. Food Chemistry. 120: 349-360. 


\section{Ayat L. K. Soude, Hania F. G. El-Neily \\ And Ashraf A. Abd El-Megeid}

Jennifer, C. Lovejoy, Marlene, M. Most; Michael Lefevre; Frank, L. Greenway and Jennifer, C. Rood (2002):

Effect of diets enriched in almonds on insulin action and serum lipids in adults with normal glucose tolerance or type 2 diabetes.The American Journal of Clinical Nutrition; 76:10006.

Jiang, R.; Manson, J.E.; Stampfer, M.J.; Liu, S.; Willett, W.C. and Hu, F.B. (2002):

Nut and peanut butter consumption and risk of type 2 diabetes in women. Journal of the American Medical Association; 288(20):2554-2560.

Koc, G. S.; Bostan, S. Z.; Con, A. H. and Sen, F. (2017):

Effects of gamma irradiation treatments and storage durations on fatty acid composition of natural hazelnut kernels. AkademikZiraatDergisi6 (2) : 95-100.

Kochar, J.; Gaziano, J.M.andDjoussé, L. (2012):

Nut Consumption and Risk of Type 2 Diabetes in the Physicians' Health Study. European Journal of Clinical Nutrition64: 75-79. 
Egyptian J. of Nutrition Vol. XXXIV No. 3 (2019)

Li, S. C.; Liu, Y. H.; Liu J. F.; Chang, W. H.; Chen, C. M. and Chen, C. Y. O. (2010):

Almond consumption improved glycemic control and lipid profiles in patients with type 2 diabetes mellitus. Metabolism. Apr, 60 (4) : 474-9.

Maclaughlin, W. L.;Wenixu, C.; Jai, H. and Humphreys, J. C. (1985):

Responseof radiochromic film dosimeter to gamma rays in different atmospheres. Radiation Physics and Chemistry. 25 (4-6) 793-805.

Mahfouz, AL-Bachier (2014):

Microbiological, sensorial and chemical quality of gamma irradiated pistachio nut (Pistacia Vera L.). The Annals of the University Dunarea de Jos of Galati Fascicle VI - Food Technology 38(2) 57-68.

\section{Mahfouz, AL-Bachier (2015):}

Assessing the effects of gamma irradiation and storage time in quality properties of almond (PrunusAmygdalus L.).nnovative Romanian Food Biotechnology 16.1-8. 


\section{Ayat L. K. Soude, Hania F. G. El-Neily \\ And Ashraf A. Abd El-Megeid}

Maity, J.P.; Chakraborty, S.; Kar, S.; Panja, S.; Jean, J.S.; Samal, A.C., Chakraborty, A. and Santra S.C. (2009):

Effect of gamma irradiation on edible seed protein, amino acids and genomic DNA during sterilization, Food Chemistry, $114,1237-1244$.

Mercanlıgil, S.M.; Arslan, P.; Alasalvar, C.; Okut, E.; Akgu, E.; Pınar A., Geyik , Tokgo L. and Shahidi F.(2007):

Effects of hazelnut-enriched diet on plasma cholesterol and lipoprotein profiles in hypercholesterolemic adult men. European Journal of Clinical Nutrition.61, 212-220.

Nishikimi, M.; Roa, N.A. and Yogi (1972):

Determination of Superoxide dismutases (SODs). Biochemistry and Biophysics search Communication, 46, 849854.

OmerB.; Mehmet A.;Necmettin Y.;NurtenS.andResulG. (2011):

Determination of fatty acid compositions of some important almond (PrunusamygdalusL.) varieties selected from Tokat province and Eagean region of Turkey. Journal of Medicinal Plants Research 5(19): 4907-4911.

Paglia, D. E. and Valentine, W. N. (1967):

Journal of Laboratory Clinical and Medicine. 70:158-169. 
Egyptian J. of Nutrition Vol. XXXIV No. 3 (2019)

Pan, A. Sun and Manson, J.E.Q. (2013).

Walnut Consumption Is Associated with Lower Risk of Type 2 Diabetes in Women. Journal ofNutrition. 143: 512-518.

Reeves, P. G.; Nielsen, F. H. and fahmy, G.C. (1993):

AIN - 93 purified diets for laboratory rodents: Final report of the American Institute of Nutrition writing committee on the reformulation of the AIN-76A rodent diet. Journal ofNutrition.,123 (11):1939-1951.

Reis, C.E.G.; Ribeiro, D.N. and Costa, N.M.B. (2012)

Acute an second-meal effects opeanuts on glycaemic response an appetite in obese women with high type 2 diabetes risk: a randomised crossover clinical trial. Birch Journal of Nutrition. 109: 2015-2023.

Richmond, W. (1973):

preparation and properties of cholesterol oxidase from nacrodiasp.and its application to enzyme assay of total cholesterol in serum.Clinical Chemistry.19:1350-1355.

Saadetkoc, G. and Ahmet, H. (2017):

Effects of gamma irradiation on chemical and sensory characteristics of natural hazelnut kernels. Postharvest Biology and Technology 123, 12-21. 


\section{Ayat L. K. Soude, Hania F. G. El-Neily \\ And Ashraf A. Abd El-Megeid}

Salas-Salvadó, J.; Bulló, M.; Pérez-Heras, A. andRos, E. (2006):

Dietaryfibre, nuts and cardiovascular disease.Brich. Journal of Nutrition.96, S45-S51.

Shahidi,F.;Alasalvar, C. and Liyana-Pathirana,M.(2007):

Anti-oxidant Phytochemicals in Hazelnut Kernel (CorylusavellanaL.) and Hazelnut Byproducts, Journal of Agricultural and Food Chemistry, 55 (4): 1212-1220.

Soheil, S.; Yadollah. A.; Ali, J. andHasan, J. (2015):

The beneficial effects of almond (PrunusamygdalusBatsch) hull on serum lipid profile and antioxidant capacity in male rats.Turkish Journalof Medicine Science.46: 1223-123.

Simone, P. ;Attilio, G.; Gianluca, .; Chiara, B. ; Antonio, I. ; Davide G. andMariangela R. (2016):

Effects of Hazelnut Consumption on Blood Lipids and Body Weight: A Systematic Review and Bayesian Meta-Analysis. Review.Nutrients 8, 747.

Stein, E. A. (1987):

Lipids, lipoprptien and apolipoprotein. In: NW Tietz,ed. Philadelhia: WB saunders, 448 - 481. 
Egyptian J. of Nutrition Vol. XXXIV No. 3 (2019)

Straznicky, N.E.; Lambert, E.A.;Grima, M.T.;Eikelis, N.;Nestel, P.J. and Dawood, T. (2012).

The effects of dietary weight loss with or without exercise training on liver enzymes in obese metabolic syndrome subjects. DiabetObes Metabolism;14(2):139-48.

Wang, R.T.;Koretz, R.L. and Yee, H.F. (2003):

Is weight reduction an effective therapy for nonalcoholic fatty liver? A systematic review.American Journal of Medicne ;;15(7) : 554-9.

Wien, M.A.; Sabate, J.M.; Ikle, D.N.; Cole, S.E. and Kandeel, F.R. (2003).

Almonds vs complex carbohydrates in a weight reduction program.IntrtionalJournalObesRelatMetabolismDisorders ;27(11):1365-1372.

Yang, J.; Liu, R.H. and Halim, L. (2009).

Antioxidant and antiproliferative activities of common edible nut seeds. LTW—Food Science and Technology 42, 1-8.

Yochum, L.; Kushi, L.; Meyer, K.; and Folsom, A. R., (1999):

Dietary flavonoid intake and risk of cardiovascular disease in postmenopausal women. American Journal of Epidemiology, 149, 943-949. 


\section{Ayat L. K. Soude, Hania F. G. El-Neily}

And Ashraf A. Abd El-Megeid

Young, D. S.(1990):

Effect of drugs on clinical laboratory test. $3^{\text {the }}$ ed 3:6-12.

Young, D.S.(2001):

Effect of disease on clinical Lab. Tests, $4^{\text {th }}$ ed 4: 3-9. 
Egyptian J. of Nutrition Vol. XXXIV No. 3 (2019)

تأثير اللوز والبندق المشع والمدعم للوجبات على بعض الخصايص البيوكيميائيه في الفئران

\title{
آيات لطقي خضر سعودي1 ـهنيه فتحي غريب النيلي1 \\ أشرف عبد العزيز عبد المجيد 2
}

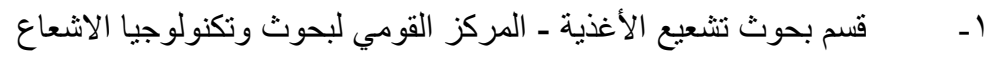 \\ هيئه الطاقه الذريه - القاهره - جمهوريه مصر العربيه. \\ قسم التخذية و علوم الأطعمة - كلبة الاقتصاد المنزلي - جامعة حلوان ـالقاهرة- جمهورية

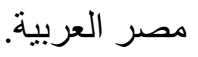

\section{المستخلص العربي}

تهدف هذه الدراسة إلى تقييم تأثير الإشعاع عند الجرعات 7 كيلوجرايو •ا كيلوجراي

على بعض التقديرات الكيميائية و الكيميائية الحيوية للمكسرات المتضمنة اللوز و البندق. استخدم في التي

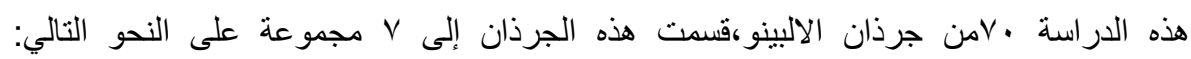

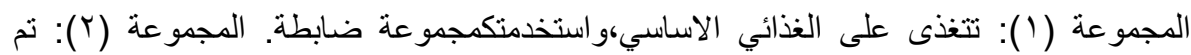

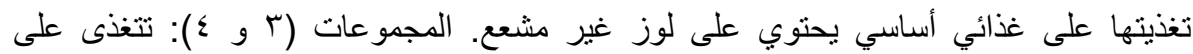

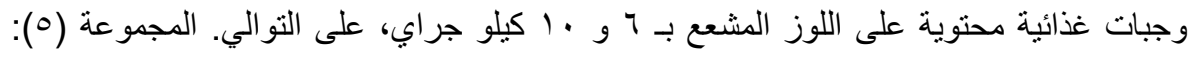

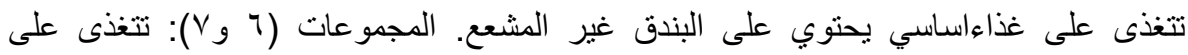

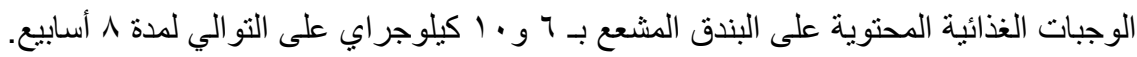

أظهر التحليل الإحصائي لللوز و البندق المعامل بجرعات 7 و ـا كيلو جراي عند بدء التجربة وبعد التخزين لمدة 1 أثنهر في التحليل الكيميائي عدم وجود فرق كبير في البروتين

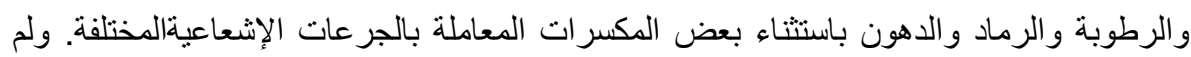




\section{Ayat L. K. Soude, Hania F. G. El-Neily \\ And Ashraf A. Abd El-Megeid}

تظهر التحاليل الكيمائية الحيوية وجود تأثير معنوي على وزن الأعضاء

وكولسترو لالليبوبروتيناتعاليه الكثافة (HDL-c) ، وكولسترول الليبوبروتينات منخفضه الكثافة

، ، و هيموجلوبين الدم ، والكولسترول الكلي ، و الجليسريداتالثناثية ، و الجلوكوز (LDL-C) وألانين أمينتر انسفير از ( ALT) و الاسبرتات امين تر انسفيراز (AST) ، سوبر اوكسيدديسمايوتيز (SOD) ، جلوتاثيونبيروكسيديز و كتاليز الكبد في مجموعات الفئران التي عوملت باللوز والبندق غير المشعع أو المشعع ، بالمقارنة بالمجموعة الضابطة التي تغذت علي الغذاء الاساسي، باستثناء

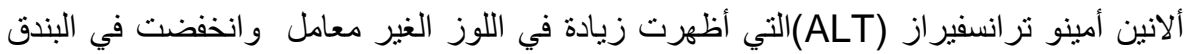
الغير معامل ، وكان هناك زيادة كبيرة في الانزيمات المضادة للأكسدة في جميع العينات. 